\title{
Maternal age, education level and migration: Socioeconomic determinants for smoking during pregnancy in a field study from Turkey
}

\author{
Isil Ergin* , Hur Hassoy, Feride A Tanik and Gokce Aslan
}

\begin{abstract}
Background: Smoking during pregnancy has been associated with socioeconomic determinants and it is recognized as the most important preventable risk factor for an unsuccessful pregnancy outcome. Turkey has national data on the prevalance of smoking during pregnancy; however there is no data on the characteristics of the high-risk population. This is a field study that aims to identify socioeconomic determinants for smoking during pregnancy as well as differentiating the daily and occasional smokers.

Method: Cross sectional study was conducted among women with 0-5 year old children living in the area served by Primary Health Care Center (PHCC) in Burhaniye, Turkey. Face-to-face interviews were conducted by the researchers during January-March 2008 at the home of the participants with $83.7 \%$ response rate $(n=256)$. The relation of "smoking during pregnacy" and "daily smoking during pregnancy" with the independent variables was determined with $x^{2}$ tests. Women's age, educational level, number of previous births, place of origin, migration, partner's educational level, poverty, perceived income, social class were evaluated. Statistical significance was achieved when the $p$ value was less than 0.05 . The variables in relation with the dependent variables in the $x^{2}$ tests were included in the forward-stepwise logistic analysis.

Results: Prevalance of smoking during pregnancy was $22.7 \%$. The majority (74.1\%) were daily smokers. Young mothers $(<20)$, low educated women and migrants were at increased risk for smoking during pregnancy. Low education and being a migrant were risk factors for daily consumption $(p<0.05)$.

Conclusions: Systematic attention should be paid to socioeconomic determinants in smoking for pregnant women, especially in countries like Turkey with high rates of infant and mother mortality and substantial health inequalities. Young mothers $(<20)$, low educated women and migrants are important groups to focus on.
\end{abstract}

\section{Background}

Maternal smoking increases perinatal mortality by $150 \%$. It is responsible for $15 \%$ of miscarriages and $20-30 \%$ of low birthweights [1]. The association between smoking and adverse pregnancy outcomes shows a dose-response relation and thus increases with the amount smoked [2]. Despite improved general knowledge of the hazards, the majority of pregnant smokers continue to smoke, however; $20 \%-40 \%$ of smokers quit during pregnancy [2-4]. There has been a decline in smoking during pregnancy in some countries in the last decades, due primarily to a

\footnotetext{
* Correspondence: isil.ergin@ege.edu.tr

1 Ege University School of Medicine, Department of Public Health, Bornova, 35100, Izmir, Turkey

Full list of author information is available at the end of the article
}

decrease in smoking initiation [2]. However, smoking prevalance have risen from $18 \%$ (1998) to $28 \%$ (2003) among young women in Turkey and for pregnant women the smoking prevalance is $15 \%[5,6]$.

Smoking was identified as one of the major causes of morbidity and mortality and question has been how this and its inequitable distribution come about. In fact, what are the causes of the causes? This brings up the questioning on the social determinants of cigarette smoking [7]. This behaviour and its social patterning are largely determined by social factors. Smoking during pregnancy has also been associated with socioeconomic determinants $[2,3,8,9]$. Socioeconomic disadvantage that relates to pregnancy outcome operates through intermediate fac- 
tors. Cigarette smoking is amongst these factors [10]. Smoking explains up to half of the adverse perinatal outcome among mothers in the lowest socioeconomic groups [11]. Considering this effect, the importance of smoking prevalence of pregnant women among different socioeconomic groups becomes more significant especially for countries like Turkey which have high rates of infant and mother mortality and substantial health inequalities.

However, Turkey has no data on the characteristics of the high-risk population. A better understanding of socioeconomic determinants is essential and will serve to identify the subgroups of the population who need most attention prenatally in policies aiming to reduce smoking.

This data, although not nationally representative, is a population-based sample executed at a town, representing urban and rural settings. This study aims to identify socioeconomic factors for smoking during pregnancy as well as differentiating the daily and occasional smokers.

\section{Methods}

\section{Setting and Data Collection}

Burhaniye is a town at the western coast of Turkey with a population of 43199. This population is engaged in farming, olive oil industry and tourism and so has a combination of characteristics of urban and rural settings where tradition and modernity intersect. The town has two Primary Health Care Centers (PHCC) giving service to their geographically identified population. Cross sectional study was conducted among women with 0-5 year-old children (756 women) living in the area served by Number 1 PHCC. Sample size was calculated to be 255 (with $50 \%$ prevalence rate and CI: $95 \%$ SE: 5\%) together with $20 \%$ substitutes, the target population was 306 . The sample which was randomly stratified by midwife-area was selected from the database of PHCC. Each midwife-area is a geographically determined area with $2500-3000$ inhabitants. The areas represent a socioeconomical distribution as well.

Face-to-face interviews were conducted by the researchers between January and March 2008 at the home of the participants with $83.7 \%$ response rate $(\mathrm{n}=$ 256). No statistically significant difference has been observed between midwife-areas in the comparison of the response rates.

\section{Variables}

\section{Maternal smoking}

The women were grouped into two categories according to their smoking history during their last pregnancy.

1. Did not smoke during pregnancy: Women who did not smoke all through pregnancy. This group was subdivided into two categories: a) Non-smoker: These women were non-smokers before their preg- nancy and did not smoke during pregnancy. Women who had once smoked but non-smokers at the onset of pregnancy were also included. b) Stopped smoking: These women were smokers (smoked at least 100 cigarettes in their lives) before pregnancy but stopped at the onset of pregnancy.

2. Smoked during pregnancy: Considering the doseresponse relation for perinatal outcomes, women who smoked during pregnancy have been classified into two groups according to frequency of consumption:

a) Occasional smoker: These women smoked during pregnancy but the consumption was not daily. b)

Daily smoker: These women smoked daily during pregnancy.

\section{Smoking status of partner during pregnancy}

The women reported the smoking status of their partner during their pregnancy. The partners were categorized into "smoked" and "did not smoke"

\section{Demographics}

Maternal age, education, number of previous births, place of origin, migration, and partner's education was questioned. Education was grouped according to the educational achievements: completion of primary school, secondary school and university. Those who had not completed primary school education but could read and write were grouped as "only literate". Those who could neither read nor write were grouped as "illiterate".

The migration described in this paper is an interprovincial migration. The women were asked about their place of origin and for any migration history. If they were not born in Burhaniye but had migrated to it, they were considered as migrants.

\section{Socioeconomic status}

Turkish Statistical Institute (TSI) advises a poverty threshold of a daily income of $4.3 \$$ per person [12]. Money earned or the earnings from other revenues were added to determine the household income. This was situated according to the determined limit: below or above the poverty level. The respondents were also asked how they perceive their welfare levels: Very good, good, moderate, low, very low. In analysis, the first two and last two categories were combined. Class position was determined according to the family head [13]. The categorization was based on the possession to the means of production and for this aim a class scheme developed by Boratav [14] was used.

\section{Statistical analysis}

For the calculation of prevalences and 95\% CI, Epi 6.0 was used. The relation of "smoking during pregnancy" and "daily smoking during pregnancy" with the independent variables was determined with $\chi^{2}$ tests. In univariate and multivariate analysis, daily smokers were compared with the group of non-smokers, stopped smoking and occa- 
sional smokers during pregnancy. Statistical significance is achieved when the $p$ value is less than 0.05 . The variables in relation with the dependent variables in the hypothesis tests were included in the forward-stepwise logistic analysis. Variables with p-values lower than 0.05 were added to the model one at a time.

The multivariate logistic regression analysis for "Did not smoke versus daily and occasional smokers" included maternal age, maternal education, place of origin, migration, poverty, perceived income and partner's smoking status.

The multivariate logistic regression analysis for "Daily smokers versus the group of non-smokers, stopped smoking and occasional smokers" included, maternal education, social class, migration, poverty, perceived income and partner's smoking status.

\section{Ethical approval}

Permission to use the official data of PHCC and to perform the field study was approved by the Regional Office of the Turkish Ministry of Health. This is a formal procedure that includes ethical evaluation within the Regional Office. Oral informed consent was sought from every woman within the study population.

\section{Results}

In this study, 256 women who had a delivery in the last five years were investigated about their smoking status before and during pregnancy.

\section{Characteristics of the sample}

The mean maternal age was $25.3 \pm 5.3$. The mean number of years after pregnancy was $2.83 \pm 1.52$. The proportion of women who had completed primary school education was $64.3 \%$. The combination of illeterate or only literate group summed to $7.5 \%$. $41.8 \%$ had migrated to Burhaniye.

\section{Prevalance of smoking}

The distribution of the smoking habits during pregnancy is presented in Figure 1. 63.28\% (95\% CI: 57.24-69.02) of women were non-smokers before pregnancy. Among the smokers, 38.30\% (95\% CI: 28.89-48.41) stopped smoking during pregnancy. Prevalance of smoking during pregnancy was $22.66 \%$ (95\% CI: 17.84-28.09). The majority (74.14\% with 95\% CI: 61.76-84.15) were daily smokers. The mean number of daily cigarette consumption of the daily smokers was $9.22 \pm 10.3($ median $=5)$. The mean number of cigarette consumption per week among the occasional smokers was $2.13 \pm 1.85($ median $=1)$.

Table 1 displays a crosstabulation of maternal smoking during pregnancy by sociodemographic characteristics of the women.

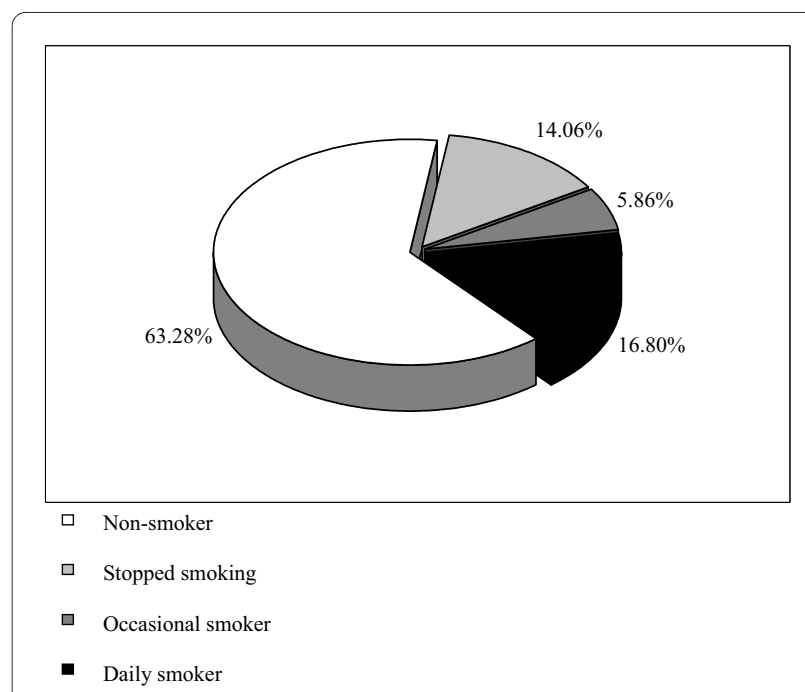

Figure 1 Distribution of the smoking habits among women during pregnancy

\section{Factors associated with smoking Univariate analysis}

"Did not smoke" versus "daily and occasional smokers". Young mothers (less than 20), low educated parents, low social classes, migrants, those below the poverty line, women with urban birthplace and women whose partners smoked during pregnancy had significantly higher rates of smoking during pregnancy $(\mathrm{p}<0.05)$.

"Daily smokers" versus the group of "non smokers, stopped smoking and occasional smokers". Low educated parents, those with low income perception, unemployed, low social classes and migrants were found significantly associated with daily smoking $(\mathrm{p}<0.05)$. Table 2 summarizes the factors associated with smoking during pregnancy and daily smoking during pregnancy.

\section{Multivariate analysis}

"Did not smoke" versus "daily and occasional smokers". This analysis presents three variables in the resultant equation; maternal age, maternal education and migration. Young women $(<20)$ are 3.4 times more likely to smoke during pregnancy. Illiterate/only literate women are 3.8 times and migrant women are 2.7 times at increased risk for smoking during pregnancy (Table 3).

"Daily smokers versus the group of "non smokers, stopped smoking and occasional smokers,". Two variables have appeared in the resultant equation; maternal education and migration. Low educated women are 6.8 times and migrant women are 2.2 times at increased risk for smoking daily (Table 3).

\section{Discussion}

In this study, smoking prevalance during pregnancy was $22.7 \%$ and this is higher than the country prevalence. 
Table 1: Smoking habits during pregnancy according to sociodemographic characteristics $(\mathbf{n}=\mathbf{2 5 6})$

\begin{tabular}{|c|c|c|c|c|c|}
\hline & & \multicolumn{2}{|c|}{ Did not smoke during pregnancy } & \multicolumn{2}{|c|}{ Smoked during pregnancy } \\
\hline & & $\begin{array}{c}\text { Non-smoker } \\
(n=162)\end{array}$ & $\begin{array}{c}\text { Stopped } \\
\text { smoking }(n=36)\end{array}$ & $\begin{array}{l}\text { Occasional smoker } \\
(n=15)\end{array}$ & Daily smoker $(n=43)$ \\
\hline & Total(n) & $\%$ & $\%$ & $\%$ & $\%$ \\
\hline \multicolumn{6}{|l|}{ Maternal Age } \\
\hline$<20$ & 37 & 54.1 & 8.1 & 10.8 & 27.0 \\
\hline $20-34$ & 201 & 64.7 & 15.9 & 5.5 & 13.9 \\
\hline$\geq 35$ & 17 & 70.6 & - & - & 29.4 \\
\hline Missing & 1 & & & & \\
\hline \multicolumn{6}{|l|}{ Maternal education } \\
\hline $\begin{array}{l}\text { Illeterate +Only } \\
\text { literate }\end{array}$ & 19 & 42.1 & 5.3 & - & 52.6 \\
\hline Primary & 137 & 67.9 & 15.3 & 5.1 & 11.7 \\
\hline Secondary+University & 99 & 61.6 & 13.1 & 8.1 & 17.2 \\
\hline Missing & 1 & & & & \\
\hline \multicolumn{6}{|l|}{ Partner's education } \\
\hline Illeterate/Only literate & 12 & 16.7 & 8.3 & - & 75.0 \\
\hline Primary & 99 & 69.7 & 13.1 & 3.0 & 14.1 \\
\hline Secondary+University & 143 & 63.3 & 14.7 & 8.4 & 13.3 \\
\hline Missing & 2 & & & & \\
\hline \multicolumn{6}{|l|}{ Previous Births } \\
\hline Nullipar & 107 & 62.6 & 15.0 & 9.3 & 13.1 \\
\hline $1+$ & 149 & 63.8 & 13.4 & 3.4 & 19.5 \\
\hline \multicolumn{6}{|l|}{ Social class } \\
\hline $\begin{array}{l}\text { Employer+Self } \\
\text { Employed }\end{array}$ & 73 & 67.1 & 15.1 & 8.2 & 9.6 \\
\hline $\begin{array}{l}\text { White-collar } \\
\text { employees }\end{array}$ & 50 & 56.0 & 20.0 & 10.0 & 14.0 \\
\hline Blue-collar workers & 92 & 68.5 & 12.0 & 3.3 & 16.3 \\
\hline $\begin{array}{l}\text { Marginal, } \\
\text { unemployed }\end{array}$ & 40 & 52.5 & 10.0 & 2.5 & 35.0 \\
\hline Missing & 1 & & & & \\
\hline \multicolumn{6}{|l|}{ Place of origin } \\
\hline Urban & 47 & 46.8 & 17.0 & 14.9 & 21.3 \\
\hline Rural & 206 & 67.5 & 13.1 & 3.9 & 15.5 \\
\hline Missing & 3 & & & & \\
\hline \multicolumn{6}{|l|}{$\begin{array}{l}\text { Migrated to } \\
\text { Burhaniye }\end{array}$} \\
\hline Yes & 107 & 54.2 & 15.0 & 6.5 & 24.3 \\
\hline No & 149 & 69.8 & 13.4 & 5.4 & 11.4 \\
\hline \multicolumn{6}{|l|}{ Poverty } \\
\hline Below poverty level & 91 & 62.6 & 11.0 & 1.1 & 25.3 \\
\hline Above poverty level & 165 & 63.6 & 15.8 & 8.5 & 12.1 \\
\hline \multicolumn{6}{|l|}{ Perceived Income } \\
\hline Very good/Good & 73 & 61.6 & 21.9 & 8.2 & 8.2 \\
\hline
\end{tabular}


Table 1: Smoking habits during pregnancy according to sociodemographic characteristics $(\mathbf{n}=\mathbf{2 5 6})(\mathrm{Continued})$

\begin{tabular}{|c|c|c|c|c|c|}
\hline Moderate & 127 & 68.5 & 11.0 & 5.5 & 15.0 \\
\hline Low/Very low & 55 & 54.6 & 10.9 & 3.6 & 30.9 \\
\hline Missing & 1 & & & & \\
\hline \multicolumn{6}{|c|}{$\begin{array}{l}\text { Partner's smoking } \\
\text { status }\end{array}$} \\
\hline Smoked & 125 & 51.2 & 20.8 & 5.6 & 22.4 \\
\hline Did not smoke & 131 & 74.8 & 7.6 & 6.1 & 11.5 \\
\hline
\end{tabular}

Young mothers $(<20)$, low educated women and migrants were at increased risk for smoking during pregnancy. Low education and being a migrant were risk factors for daily consumption.

In this study the retrospective assessment has been 2.8 years after pregnancy approximately. Recall bias has been questioned in previous studies, because the recollection of events and behaviors with recall bias is a serious threat to the use of retrospective data. However, considering smoking behavior in pregnancy, recall accuracy was ascertained in studies even five or six years after pregnancy [15]. The saliency of pregnancy as a life event and the social stigmatism associated with smoking during pregnancy is assumed to create this accuracy. Thus, in this study, the 2.8 years after pregnancy should not be considered as questionable for validity. Self-report is a limitation of this study. However, 2008 systematic review on smoking during pregnancy, presents self-report as the main limitation of all studies included in the review and addresses social desirability as an important source of bias resulting in underreporting of actual prevalence [1]. This study, tried to diminish the social desirability bias. Burhaniye was a region where home visits were an essential part of primary care and midwives working at the area knew most of the women with their names. Provider sincerity was accomplished at the area, long before our study was executed; this was an important point in reducing the social desirability bias. As the research team visited the houses, they presented themselves as coming via the primary care center and that the midwives knew about this visit. This increased the response rate as well as the sincerity of the interview. The information elicited from the women at their homes rather than a health care setting and the fact that face-to-face interview was used rather than a self-administrated questionnaire made the information more reliable and thus pointed out the socioeconomic determinants more truly.

In DHS Turkey 2003, 15\% of pregnant women report that they smoke regularly and among these pregnant women, $41 \%$ smoke 3-5 cigarettes, $14 \%$ smoke 6-9 cigarettes, and $15 \%$ smoke 10 or more cigarettes [6]. The high prevalence of smoking during pregnancy in this study may be attributed to the urban-rural characteristics of the town as well as its location in the Western region of Tur- key where smoking prevalence of women is 32.3\% [6]. Among the smoker group $38.7 \%$ quitted during pregnancy which is in accordance with studies reporting 20$40 \%$ of quitting during pregnancy [2].

Studies have shown that smoking prevalence during pregnancy is determined by social factors, especially educational level and social class $[9,16]$. The influence of social class on child and mother health is exerted through intermediate factors. Maternal age has been declared as one of these intermediate factors [17]. In this study, smoking was more prevalent among the young mothers. The increased risk for smoking during pregnancy for this risky age group has been 3.4 fold. The very young mothers are considered to be at higher risk for perinatal outcomes [18]. The risks of smoking during pregnancy add and make a double burden for this risky age group [2]. Very young women are shown to be more likely to smoke during pregnancy. They are probably unaware of the health related consequences of their tobacco use [19]. Maternal age becomes an intermediate determinant [6] where it serves as a media for the "causes of the causes" for cigarette smoking during pregnancy [7]. The young mothers and those of low socioeconomic status all have one thing in common: on average they have to cope with more stress, less favorable social networks and poorer economic conditions. All these make it harder to quit smoking during pregnancy because smoking is a practice which promises stres relief, albeit short-lived $[1,20]$. Smoking enhances the sense of well being and is used as a tool to cope with negative mood or stress experiences [21]. It has been declared that half the excess risk of adverse perinatal outcomes in the lowest socioeconomic group is explained by maternal smoking [11], so the efforts aiming to reduce smoking during pregnancy especially among the deprived groups is an important intervention for perinatal health.

In this study, in univariate analysis partner's smoking status was significantly associated with maternal smoking during pregnancy. Smoking status of partner is a well documented determinant of maternal smoking during pregnancy [22]. Smokers are less likely to give up the habit if others smoked daily at home [3].

An individual's probability of smoking is independently associated with a vast array of different indicators of 
Table 2: Factors associated with smoking during pregnancy and daily smoking

\begin{tabular}{|c|c|c|c|c|c|c|}
\hline & \multicolumn{6}{|c|}{ SMOKING STATUS } \\
\hline & \multicolumn{3}{|c|}{ Smoking during pregnancy } & \multicolumn{3}{|c|}{ Daily smoking } \\
\hline & $\begin{array}{l}\text { Daily and } \\
\text { occasional smoker } \\
\text { n(\%) }\end{array}$ & $\begin{array}{l}\text { Did not } \\
\text { smoke } \\
\text { n(\%) }\end{array}$ & $\mathbf{p}$ & $\begin{array}{l}\text { Daily smoker } \\
\text { n(\%) }\end{array}$ & $\begin{array}{l}\text { Non smoker, } \\
\text { stopped smoking, } \\
\text { occasional smoker } \\
\text { n(\%) }\end{array}$ & $\mathbf{p}$ \\
\hline \multicolumn{7}{|l|}{ Maternal Age } \\
\hline$<20$ & 14(37.8) & $23(62.2)$ & 0.039 & $15(40.5)$ & $22(59.5)$ & 0.215 \\
\hline $20-34$ & $39(19.4)$ & $162(80.6)$ & & $53(26.4)$ & 148(73.6) & \\
\hline$\geq 35$ & $5(29.4)$ & 12(70.6) & & $5(29.4)$ & 12(70.6) & \\
\hline \multicolumn{7}{|l|}{$\begin{array}{l}\text { Maternal } \\
\text { education }\end{array}$} \\
\hline $\begin{array}{l}\text { Illeterate+only } \\
\text { literate }\end{array}$ & $10(52.6)$ & $9(47.4)$ & 0.002 & $10(52.6)$ & $9(47.4)$ & 0.000 \\
\hline Primary & $23(16.8)$ & $114(83.2)$ & & 16(11.7) & $121(88.3)$ & \\
\hline $\begin{array}{l}\text { Secondary+U } \\
\text { niversity }\end{array}$ & $25(25.3)$ & $74(74.7)$ & & $17(17.2)$ & $82(82.8)$ & \\
\hline \multicolumn{7}{|l|}{$\begin{array}{l}\text { Partner's } \\
\text { education }\end{array}$} \\
\hline $\begin{array}{l}\text { Illeterate+only } \\
\text { literate }\end{array}$ & $9(75.0)$ & $3(25.0)$ & 0.000 & $9(75.0)$ & $3(25.0)$ & 0.000 \\
\hline Primary & $17(17.2)$ & $82(82.8)$ & & $14(14.1)$ & $85(85.9)$ & \\
\hline $\begin{array}{l}\text { Secondary+U } \\
\text { niversity }\end{array}$ & $31(21.7)$ & $112(78.3)$ & & 19(13.3) & 124(86.7) & \\
\hline \multicolumn{7}{|l|}{$\begin{array}{l}\text { Previous } \\
\text { births }\end{array}$} \\
\hline Nullipar & $23(21.5)$ & $84(78.5)$ & 0.802 & 14(13.1) & 93(86.9) & 0.178 \\
\hline $1+$ & $34(22.8)$ & $115(77.2)$ & & $29(19.5)$ & $120(80.5)$ & \\
\hline \multicolumn{7}{|l|}{ Social class } \\
\hline $\begin{array}{l}\text { Employer+Self } \\
\text { Employed }\end{array}$ & 13(17.8) & $60(82.2)$ & 0.088 & $7(9.6)$ & $66(90.4)$ & 0.006 \\
\hline $\begin{array}{l}\text { White-collar } \\
\text { employees }\end{array}$ & $12(24.0)$ & $38(76.0)$ & & $7(14.0)$ & $43(86.0)$ & \\
\hline $\begin{array}{l}\text { Blue-collar } \\
\text { workers }\end{array}$ & 18(19.6) & $74(80.4)$ & & $15(16.3)$ & 77(83.7) & \\
\hline $\begin{array}{l}\text { Marginal, } \\
\text { unemployed }\end{array}$ & 15(37.5) & $25(62.5)$ & & $14(35.0)$ & $26(65.0)$ & \\
\hline \multicolumn{7}{|l|}{$\begin{array}{l}\text { Place of } \\
\text { origin }\end{array}$} \\
\hline Urban & $17(36.2)$ & $30(63.8)$ & 0.013 & 10(21.3) & $37(78.7)$ & 0.339 \\
\hline Rural & $40(19.4)$ & 166(80.6) & & $32(15.5)$ & $174(84.5)$ & \\
\hline \multicolumn{7}{|l|}{$\begin{array}{l}\text { Migrated to } \\
\text { Burhaniye }\end{array}$} \\
\hline Yes & $33(30.8)$ & $74(69.2)$ & 0.008 & $26(24.3)$ & $81(75.7)$ & 0.007 \\
\hline No & $25(16.8)$ & $124(83.2)$ & & 17(11.4) & 132(88.6) & \\
\hline
\end{tabular}


Table 2: Factors associated with smoking during pregnancy and daily smoking (Continued)

\begin{tabular}{llllll}
\hline $\begin{array}{l}\text { Below poverty } \\
\text { level }\end{array}$ & $24(26.4)$ & $67(73.6)$ & 0.000 & $23(25.3)$ & $68(74.7)$ \\
$\begin{array}{l}\text { Above poverty } \\
\text { level }\end{array}$ & $34(20.6)$ & $131(79.4)$ & & $20(12.1)$ & $145(87.9)$ \\
$\begin{array}{l}\text { Perceived } \\
\text { Income }\end{array}$ & & & & \\
$\begin{array}{l}\text { Very good/ } \\
\text { good }\end{array}$ & $12(16.4)$ & $61(83.6)$ & 0.039 & $6(8.2)$ & $67(91.8)$ \\
$\begin{array}{l}\text { Moderate } \\
\text { Low/Very low }\end{array}$ & 26(20.5) & $19(34.5)$ & & $19(15.0)$ & $108(85.0)$ \\
$\begin{array}{l}\text { Partner's } \\
\text { smoking } \\
\text { status }\end{array}$ & & $36(65.5)$ & $17(30.9)$ & $38(69.1)$ \\
$\begin{array}{l}\text { Smoked } \\
\text { Did not smoke }\end{array}$ & $23(17.6)$ & & & \\
\hline
\end{tabular}

social disadvantage. Any marker of disadvantage that can be envisaged and measured whether personal, material or cultural is likely to have an independent association with cigarette smoking [20]. Migrants in our population can be considered as those having this socioeconomic disadvantage and they were shown to have a higher prevalance of smoking during pregnancy. Internal migration has had a great impact on Turkey's population dynamics for decades. According to the 2000 population census, nearly $28 \%$ of the population was born in a different province that they now reside in. It is generally a result of a transfer of labor from low productive to high productive areas [23]. In this sense, Burhaniye has been an attractive town with its well known place in farming, olive oil industry and tourism. However, Ozmucur and Silber showed that internal migration from rural to urban areas increased the income inequalities rather than acting as an equilibrating mechanism and closing the gap [24]. Thus, the internal migrants can be described as disadvantageous groups of the population, especially at urban settings. The multivariate analysis showed that migrants were at increased risk for smoking during pregnancy as well as an increased risk for smoking daily. Those who were born in the urban were more likely to smoke. This may be attributed to the higher prevalances of cigarette smoking for women in urban areas rather than an increased smoking prevalance in pregnancy. Smoking prevalance of women in Turkey is higher in urban areas $(32.8 \%)$ than in rural (14.9\%) [6]. Women originating from urban places were culturally more welcome to smoking than those originating from rural settings.

The number of cigarettes the mother smokes during pregnancy increases the perinatal risk [25], thus for this study, daily smokers are at increased risk for perinatal outcomes. Studies have shown that the risk of SGA births, preterm births and stillbirths increases with amount smoked and smoking cessation makes improvements in these risks [3]. In this study, low educated women and migrants were at increased risk for smoking daily. The daily cigarette consumption in this group with low socioeconomic conditions signals the aggravation of risks for poor fetal growth and thus unhealthy perinatal outcomes [26-28].

Smoking cessation programs need to be implemented in all maternity care settings and attention to smoking behaviour together with support for smoking cessation and relapse prevention needs to be a routine a part of antenatal care as the measurement of blood pressure [29]. Primary care services are a very important source of prenatal care especially for low income, low educated and migrant populations in developing countries [30]. This makes their role more important, in the efforts to reduce smoking during pregnancy. All primary care settings are of great importance. Considering that, implementation should be at all settings, home visits by midwives deserve special focus. Home visits are an important part of the comprehensive prenatal care services that entail outreach efforts to improve enrollment in prenatal care. This is especially important for low income populations [31]. Moreover, gender-based barriers to utilization, especially restrictions that prevent women from leaving their homes to access health services on their own are thus overcome. The conception of health systems as core social institutions moves the analysis beyond a simplistic view of healthcare as a technical, biomedical fix to a recognition that both health and healthcare are deeply embedded in broader webs of social and economic forces. Priority must be given to primary care facilities and to community-based primary care activities, often linked to the health care facilities, especially when they truly empower the communities they serve [32]. Moreover, the unreliability of self-report as a measure of smoking status 
Table 3: Multivariate logistic regression results for two logistic models*

\begin{tabular}{|c|c|}
\hline & OR $(95 \% \mathrm{Cl})$ \\
\hline \multicolumn{2}{|l|}{$\begin{array}{l}\text { "Did not smoke" versus } \\
\text { "daily and occasional } \\
\text { smoker" }\end{array}$} \\
\hline \multicolumn{2}{|l|}{ Maternal age } \\
\hline$<20$ & $3.41(1.40-8.35)^{* *}$ \\
\hline $20-35$ & 1.00 \\
\hline$\geq 35$ & $1.15(0.27-4.86)$ \\
\hline \multicolumn{2}{|l|}{ Maternal education } \\
\hline Illiterate/only literate & $3.79(1.14-12.55)^{* *}$ \\
\hline Primary education & $0.79(0.38-1.65) 1.00$ \\
\hline \multicolumn{2}{|l|}{ Secondary/University } \\
\hline \multicolumn{2}{|l|}{ Migration } \\
\hline Migrated & $2.68(1.31-5.48)^{* *}$ \\
\hline Did not migrate & 1.00 \\
\hline \multicolumn{2}{|l|}{$\begin{array}{l}\text { "Daily smokers" versus the } \\
\text { group of "non smoker, } \\
\text { stopped smoking and } \\
\text { occasional smoker" }\end{array}$} \\
\hline \multicolumn{2}{|l|}{ Maternal education } \\
\hline Illiterate/only literate & $6.79(2.03-22.77)^{* *}$ \\
\hline Primary education & $0.91(0.46-1.81)$ \\
\hline Secondary/University & 1.00 \\
\hline \multicolumn{2}{|l|}{ Migration } \\
\hline Migrated & $2.16(1.12-4.15)^{* *}$ \\
\hline Did not migrate & 1.00 \\
\hline
\end{tabular}

* The two logistic models are: 1 . Did not smoke versus daily and occasional smoker and 2. Daily smokers versus the group of non smoker, stopped smoking and occasional smoker.

** $\mathrm{p}<0,05$

in the health care settings [29] may also be overcome at the home of the women with more sincere atmosphere shared with her midwife. For high income countries the most effective intervention has been reported to be providing incentives. Not much is known about the development or implementation of such interventions or their effectiveness in low or middle income countries [33]. For Turkey, further research is necessary in evaluating and comparing the effectiveness of such programmes in the light of the focus on social inequalities presented in this paper.

Studies show that, women who stop smoking in early pregnancy had birthweights essentially the same as nonsmokers and the risk of stillbirth also reduced to that of nonsmokers $[34,35]$. Considering the effect of smoking on adverse perinatal outcomes, the importance of high smoking prevalence of pregnant women of low socioeco- nomic conditions presented in this study becomes more significant. Turkey is a country with high levels of infant mortality and the rate increases dramatically for groups with low education and low socioeconomic status [36]. For these groups, the unhealthy living conditions, bariers for access to heath care and incapacity of the health care system for access to obstetric emergency services may combine with the perinatal risks of smoking during pregnancy. Smoking during pregnancy fuels inequities in perinatal outcomes. To reduce inequalities later in life it is important to reduce inequalities at birth [37].

\section{Study limitations}

Information on smoking was elicited from the women themselves. Self reported information of smoking prevalance during pregnancy is probably underestimated.

\section{Conclusions}

Systematic attention should be paid to socioeconomic determinants in smoking for pregnant women. This is vital, especially for countries like Turkey, with high rates of infant and mother mortality and substantial health inequalities. Young maternal age groups, low educated women and migrants are important groups to focus on. Acknowledging smoking as a major source of social differences in health and adressing them even in intrauterine life will help to design better smoking intervention programs and to develop opportunities for better perinatal health.

Competing interests

The authors declare that they have no competing interests.

\section{Authors' contributions}

$\mathrm{IE}, \mathrm{HH}$ and FAT have made substantial contributions to the conception and design of the study, IE, $\mathrm{HH}$ and $\mathrm{GA}$ contributed to the acquisition of data; $\mathrm{IE}, \mathrm{HH}$ and FAT have made significant contributions to the analysis and interpretation of the data; IE, HH and GA were involved in drafting the manuscript and revising it critically for important intellectual content; and IE and $\mathrm{HH}$ gave final approval of the version to be published. All authors read and approved the final manuscript.

\section{Author Details}

Ege University School of Medicine, Department of Public Health, Bornova, 35100, Izmir, Turkey

Received: 22 February 2010 Accepted: 9 June 2010

Published: 9 June 2010

\section{References}

1. Schneider S, Schutz J: Who smokes during pregnancy? A systematic literature review of population-based surveys conducted in developed countries between 1997 and 2006. Eur J Contracep Repr 2008, 13(2):138-147

2. Cnattingius S: The epidemiology of smoking during pregnancy: Smoking prevalence, maternal characteristics, and pregnancy outcomes. Nicotine Tob Res 2004, 6(Supplement 2):125-140.

3. Cnattingius $S$, Lindmark $G$, Meirik $O$ : : Who continues to smoke while pregnant? J Epidemio/ Commun H 1992, 46(3):218-21

4. Palma S, Pérez-Iglesias R, Pardo-Crespo R, Llorca J, Mariscal M, DelgadoRodríguez M: Smoking among pregnant women in Cantabria (Spain): 
trend and determinants of smoking cessation. BMC Public Health 2007, 7:65.

5. Republic of Turkey Ministry of Health: National Tobacco Control Programme and Action Plan of Turkey 2008-2012. Ankara 2008.

6. Hacettepe University Institute of Population Studies, Ministry of Health General Directorate of Mother and Child Health and Family Planning, State Planning Organization and European Union : Turkey Demographic and Health Survey 2003. Ankara, Turkey

7. Commission on Social Determinants of Health, Interim Statement Comission on Social determinants of Health (CSDH): Achieving health equity from root causes to fair outcomes. IER/EQH, WHO 2007.

8. Goy J, Dodds L, Rosenberg MW, King WD: Health-risk behaviours: examining social disparities in the occurrence of stillbirth. Paediatr Perinat Ep 2008, 22(4):314-20.

9. Villalbi JR, Salvador J, Cano-Serral G, Rodriguez-Sanz MC, Borrell C Maternal smoking, social class and outcomes of pregnancy. Paediatr Perinat Ep 2007, 21(5):441-447.

10. Kramer MS, Séguin L, Lydon J, Goulet L: Socio-economic disparities in pregnancy outcome: why do the poor fare so poorly? Paediatr Perinat Ep 2000, 14(3):194-210.

11. Gissler M, Meriläinen J, Vuori E, Hemminki E: Register based monitoring shows decreasing socioeconomic differences in Finnish perinatal health. J Epidemiol Commun H 2003, 57:433-439.

12. Turkish Statistical Institute: : Results of 2004 poverty study. Turkish Statistical Institute News Bulletin 2006:27.

13. Kunst $A E$, Mackenbach JP: Measuring socioeconomic inequalities in health. WHO Copenhagen 1995.

14. Boratav K: Istanbul ve Anadolu'dan Sinif Profilleri (Class profiles from Istanbul and Anatolia). 2nd edition. Ankara: Imge; 2004.

15. Hensley Alford SM, Lappin RE, Peterson L, Johnson CC: Pregnancy Associated Smoking Behavior and Six Year Postpartum Recall. Matern Child Health J 2009, 13:865-872.

16. Lanting Cl, Buitendijk SE, Crone MR, Segaar D, Gravenhorst JB, Wouwe JP. Clustering of socioeconomic, behavioural, and neonatal risk factors for infant health in pregnant smokers. PLOS ONE 2009, 4(12):e8363.

17. Kogan MD: Social causes of low birthweight. JR Soc Med 1995, 88:611-615.

18. de Sanjose S, Roman E: Low birthweight, preterm, and small for gestational age babies in Scotland, 1981-1984. J Epidemiol Commun H 1991, 45:207-210.

19. Owen L, Bolling K: Smoking and pregnancy - A survey of knowledge, attitudes and behaviour. London: Health Education Authority 1997.

20. Layte R, Whelan CT: Explaining Social Class Inequalities in Smoking: The Role of Education, Self-Efficacy, and Deprivation. European Sociological Review 2009, 25:399-410.

21. Goedhart G, Wal MF, Cuijpers P, Bonsel GJ: Psychosocial problems and continued smoking during pregnancy. Addict Behav 2009, 34(4):403-406.

22. Lemola S, Grob A: Smoking cessation during pregnancy and relapse after childbirth: The impact of the grandmother's smoking status. Matern Child HIth J 2008, 12(4):525-533.

23. Gokhan A, Filiztekin A: The determinants of internal migration in Turkey. In International Conference on Policy Modelling. EcoMod 2008 EcoMod Press. Brussels, Belgium; 2008.

24. Ozmucur S, Silber J: Spatial Inequality in Turkey and the Impact of Internal Migration. Cornel//LSENWider Conference on Spatial Inequality and Development. London, The United Kingdom 2002.

25. ISD Scotland: Scottish perinatal and infant mortality and morbidity report. Edinburgh. ISD Scotland 2003.

26. Cnattingius $S$ : Does age potentiate the smoking-related risk fetal growth retardation? Early Hum Dev 1989, 20(3-4):203-211.

27. Fox SH, Koepsell TD, Daling JR: Birthweight and smoking during pregnancy-effect modification by maternal age. Am J Epidemiol 1994, 139(10):1008-1015.

28. Wen SW, Goldenberg RL, Cutter GR, Hoffman HJ, Cliver SP: Smoking, maternal age, fetal growth and gestational age at delivery. Am J Obstet Gynecol 1990, 162(1):53-58.

29. Oliver S, Oakley L, Lumley J, Waters E: Smoking cessation programmes in pregnancy: Systematically addressing development, implementation, women's concerns and effectiveness. Health Education Journal 2001 60:362.
30. Starfield B: Primary care balancing health needs, services, and technology. New York Oxford University Press 1988.

31. Alexander GR, Kotelchuck M: Assessing the role and effectiveness of prenatal care: history, challenges, and directions for future research. Public Health Rep 2001, 116(4):306-16.

32. UN Milennium Project: Who's got the power? Transforming health systems for women and children. Taskforce on child health and maternal health 2005.

33. Lumley J, Chamberlain C, Dowswell T, Oliver S, Oakley L, Watson L: Interventions for promoting smoking cessation during pregnancy. Cochrane Database of Systematic Reviews 2009, 3:CD001055.

34. MacArthur C, Knox EG: Smoking in pregnancy. Effects of stopping at different stages. BJOG-Int J Obstet Gy 1988, 95(6):551-555.

35. Wisborg K, Kesmodel U, Henriksen TB, Olsen SF, Secher NJ: Exposure to tobacco smoke in utero and the risk of stilbirth and death in the first year of life. Am Journal Epidemiol 2001, 154(4):322-327.

36. Hacettepe University Institute of Population Studies, Ministry of Health General Directorate of Mother and Child Health and Family Planning, State Planning Organization and European Union: Turkey Demographic and Health Survey 2008. Ankara, Turkey.

37. Fairley L, Leyland AH: Social class inequalities in perinatal outcomes: Scotland 1980-2000. J of Epidemio/ Commun H 2006, 60:31-36.

\section{Pre-publication history}

The pre-publication history for this paper can be accessed here: http://www.biomedcentral.com/1471-2458/10/325/prepub

doi: 10.1186/1471-2458-10-325

Cite this article as: Ergin et al., Maternal age, education level and migration: Socioeconomic determinants for smoking during pregnancy in a field study from Turkey BMC Public Health 2010, 10:325

\section{Submit your next manuscript to BioMed Centra} and take full advantage of:

- Convenient online submission

- Thorough peer review

- No space constraints or color figure charges

- Immediate publication on acceptance

- Inclusion in PubMed, CAS, Scopus and Google Scholar

- Research which is freely available for redistribution 